\title{
Editorial
}

\section{Customer experience}

Journal of Brand Management (2007) 15, 85-88. doi:10.1057/palgrave.bm.2550127; published online 19 October 2007

When was your last poor customer experience? Last week? Yesterday? Half an hour ago? One thing is for sure, although I am not a gambling man, I'd be prepared to wager that 90 per cent of us reading this won't have gone more than a week without suffering some kind of uncomfortable, even disastrous, customer experience.

It is almost ten years since I first worked in any great depth on the definition of 'customer experience' while Director of Global Brand Strategy at Hewlett Packard, and almost 15 years since I first presented on 'aligning the organisation to deliver the brand experience'-now widely referred to as 'Employee Engagement or Embedding'. Why has so little changed?

Despite all the excellent work and thinking around CRM (NOT the ITbased, sales focused Siebel CRM), around the understanding of human response and getting the best out of employees and partners, customer complaints are still soaring and our actual experiences are still as bad!

Our friends at Google would have us find huge numbers of references to terms like 'Customer Experience' (219 million), and 'Employee Experience' (46.4 million), which lends weight to the fact that this is a truly global challenge. And I am delighted to say that in this special issue of the Journal, we have contributions from august members of our global brand community (namely authors from Norway and Australia), to add to our UK authors. From the purely academic to the academic/case study, to pure practice papers, I hope that you will find the content thought-provoking, useful and, hopefully, delivering a good 'customer experience'!

It is a huge honour for me to be guest editing this issue which features people I know and greatly respect for their contribution to the never-ending challenge we all face of making sense out of something so simply put in the seminal paper by Ronald Coase in 1937, ${ }^{1}$ when he described the purpose of business as 'Fulfilling customer needs via relationships you maintain'. This simply constructed set of seven words say absolutely everything one needs to know about being successful in business and brand management.

Before picking up on some excellent discussion points from our authors, I would like to revisit these words, especially the word 'relationships', and to consider how they remind us all of what our marketing task is, and how we deliver on that. One of the most frequently asked questions on my conference platforms is 'how can we get the respect/budget for marketing in the boardroom?'. The answer is actually quite simple-understand the language of the boardroom. This is not the same as insider marketing-speak; something all functions have and need to operate. In financial terms, our marketing task is:

'Raise and accelerate, prolong and minimise risk to cash flows'

This in turn will produce a rise in the company's brand equity which, when added to the Net Asset Value of the business, gives the company its market valuation (simplified) - and the higher that is, the happier are its Board members and shareholders. 


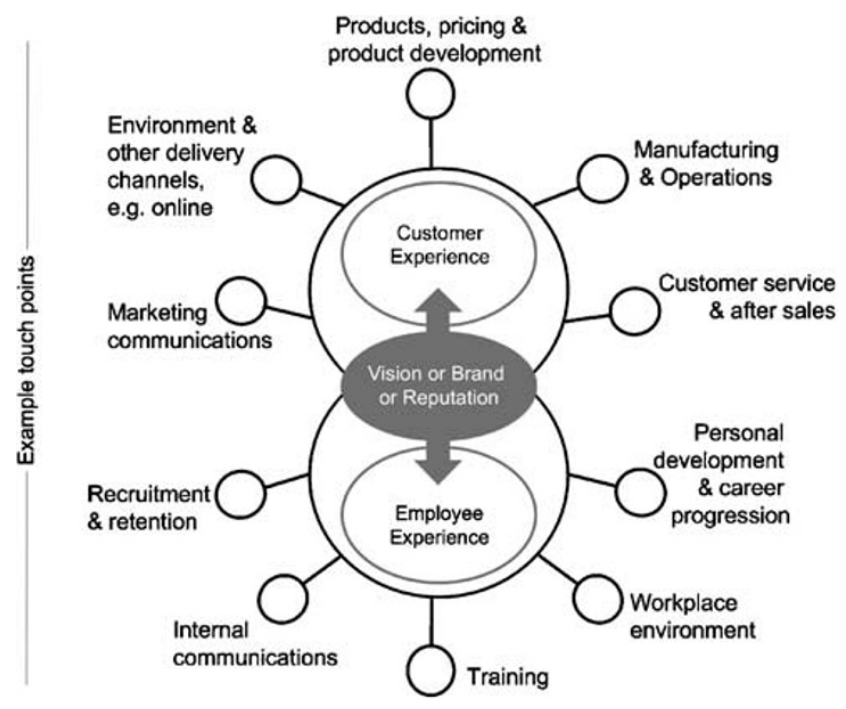

Figure I Brand: The fundamental link between all aspects of experience

So, what has all this to do with customer experience? Well, cash flow effects are achieved through a complex set of relationships with customers, employees and partners. In fact, we could define Brand equity as 'The value of the relationships that build and sustain cash flows'.

Figure 1 details a schematic of how Brand Experience/Reputation is the bridge between the customer and the employee experience, and observed through this lens, it is hardly surprising that the world seems to be waking up, at last, to the importance of both the customer, and by absolute connection, the employee, experience.

With that, I'd like to take a brief walk through the contributions in this special issue. The first contribution, by Professor Adrian Payne and Dr Pennie Frow, both based in Sydney, Australia, considers what a perfect customer experience might look like, and how it might be achieved at reasonable cost. Given that the prime reason why companies still appear to be failing to actually execute on all their good intentions is cost, Adrian and Pennie have considered the thinking around this and give us a couple of very good case studies (TNT and Guinness) that help their points.

Service quality is another key area that is often the source of either great satisfaction or dissatisfaction, and Dr Stan Maklan and Philipp Klaus of Cranfield School of Management share their own thinking around whether SERVQUAL really is measuring the right things for customer experience management. They also raise that old thorn about service branding being different to product branding. My own view is that I have yet to be convinced it is any different in fundamentals, but I have little doubt that this paper will stimulate strong debate!

Another wonderfully readable practice paper comes from Patrick Harris, formerly Director of Creativity for Orange from its very early days. Patrick also managed the strategic think tank for Hans Snook, the Orange founder, and his style is engaging and direct, as he introduces us to some challenging ideas. For instance, 'Inside organisations, it is not buy-in that is necessary, but momentum', and his 
rationale for that being 'Momentum taps into the collective wisdom of the staff and invites their participation'. I am absolutely certain that this contribution will provide many of you with an entertaining and provoking set of ideas.

Richard Mosley's paper delves even deeper into the world of customer experience being delivered through employee behaviour, Richard is MD of People in Business, and he gives us a good, practical expose on what he calls 'employer brand'. While this term is for many just another expression of what we have all been doing under the banner of 'internal branding' or 'employee embedding', Richard takes a slightly different view. Importantly, he has a wealth of experience in actually executing and delivering on making employees understand their roles and responsibilities. This is another great read, and is full of good ideas, from which we all can find something to take away and learn.

Last but not least is a paper from Nicholas Ind, Norway, which was written in conjunction with a colleague, Associate Professor Rune Bjerke of Oslo School of Management. Nicholas is the author of an established text on employee branding called 'Living the Brand'. ${ }^{2}$ These two give us another concept to consider called 'Participatory Market Orientation', which is 'an organisation-wide approach to enhancing brand equity'. This will certainly be another subject for debate!

I am most grateful for all our contributions to this special issue; as all of you who have ever tried to write anything will know, it is a big commitment and sharing thinking is a very selfless way to contribute to the development of our profession.

If I may just finish with a few words of my own around this whole subject, and specifically on something I have been calling 'Humanity Based Strategy' (HBS) for a number of years now.
Through my involvement in a terrific global think-tank on branding, The Medinge Group (www.medinge.org) I first went into detail research around anthropology and branding which I covered in our first book 'Beyond Branding' in 2003. ${ }^{3}$ This subsequently developed into HBS as I came to the conclusion that there are actually just three key tenets to successful long-term sustainable competitive advantage:

(1) People are People First: It really doesn't matter where in an organisation you sit, or whether you are in the role of a customer or a supplier, ALL of us have an inbuilt human reaction to every 'experience' we have, in any circumstance- and nothing any of us can do can change that fact. Unless we try to understand what our customers, employees and partners do feel through each of those 'moments of truth' that Jan Carlsson spoke about all those years ago, and do something about it, then we are at serious risk of losing business, or worse, a customer or employee, for good.

(2) Manage the Reality Gap:This is simply the practice of getting under the skin of exactly what current experiences look and feel like based on expectations, and ensuring there is as little difference as possible. However good an organisation may be, there will always be some areas of dissonance between what they think they are projecting/promising, and what the customer or employee is actually experiencing.

(3) Create Trust and Relevance: Probably the two most powerful words, if not in the world, then certainly in the world of successful marketing and brand management. Based on the 
principle of a brand being a promise, and all of us knowing very well how hard it hurts when a promise is broken, and how, commercially, it is relatively easy to walk away if that happens. The short-form definition of brand management I developed 20 years ago still holds true-Make a Promise, Keep a Promise.

None of this is rocket science! As my hair has greyed, and at least has remained on my head(!), I have wondered at the awesome incompetence of organisations to actually execute on all of their stated good intentions to ensure that we enjoy buying from them, whether they be major corporations or the local restaurant or hardware store.

Will we ever get it 100 per cent right? I think that is highly unlikely. Our contributors to this will, I hope, at least, however, help those that do want to make progress, understand a little more about what their challenges may be. Then again, there are those, fortunately few, companies that don't seem to want to know, as a quick look through some of the media coverage surrounding, for example, Ryanair's 'customer experience', would indicate. A future paper on the paradox that is business success through poor attitude to customers, perhaps?!

\section{Ian Ryder Guest Editor Ian@uffindellwest.com}

\section{References}

(1) Williamson, O. E and Winter, S. G. (1993) 'The Nature of The Firm: Origins, Evolution and Development', Oxford University Press, New York.

(2) Ind, N. (2004) 'Living the Brand', 2nd edn, Kogan Page, London.

(3) Ind, N. (ed.) 'Beyond Branding', Kogan Page, London, Hardback 2003, Paperback 2005, ISBN 0-7494-4399-5. 